NATALIA MARIA RUMAN

Forum Pedagogiczne

Uniwersytet Ślaski

2015/1

Cieszyn

\title{
SZTUKA SAKRALNA A PRZEŻYCIE TANATOLOGICZNE - ASPEKT TEOLOGICZNO-PEDAGOGICZNY
}

\author{
Sztuka przedstawia wydarzenia \\ poważne i wielkie przez co wzbudza litość i trwoge, \\ dokonując oczyszczenia uczuć. \\ Arystoteles
}

\begin{abstract}
Streszczenie: Wychowanie przez sztukę mające prowadzić do rozwoju człowieka, do równowagi funkcji intelektualnych, emocjonalnych i motywacyjno-wolitywnych, jest często pomijanym aspektem. Sztuka powinna opanować nasze życie. Świat wyobraźni formowany jest od dzieciństwa, poddawany różnym perturbacjom, różnicuje się w trakcie dorastania i doświadczeń. Są to również doświadczenia przykre, smutne, trudne. Sztuka sakralna nie pomija takich doznań w życiu człowieka. Przedstawia śmierć często w taki sposób, by odbiorcę zachęcić do refleksji i wzbogacić jego życie. Sztuka wtedy staje się narzędziem ogólnego kształtowania człowieka, które ma umożliwić mu życie w sposób spontaniczny i twórczy, a także pomóc osiągnąć harmonię życia zmysłowego, uczuciowego i intelektualnego.
\end{abstract}

Słowa kluczowe: edukacja alternatywna, kształcenie, wychowanie, kultura, sztuka, sens życia, tanatologia, eschatologia

\section{Refleksje wstępne}

Dla dziecka śmierć jest pojęciem abstrakcyjnym, trudnym do zrozumienia. Jednocześnie jednak jest zjawiskiem nieodłącznie towarzyszącym ludzkiej egzystencji. Stąd ma ona dla dziecka szczególne znaczenie, zwłaszcza gdy weźmie się pod uwagę ograniczone jeszcze rozumienie świata i nieukształtowane w pełni dziecięce strategie radzenia sobie z przeżyciami towarzyszącymi temu traumatycznemu wydarzeniu. Psychologowie przekonują, że są one jednym z najważniejszych czynników występowania zaburzeń depresyjnych u dzieci.

W dziecięcej percepcji śmierci wyróżnia się trzy aspekty: kształtowanie się obrazu śmierci, postrzeganie własnej śmierci i postawy dzieci wobec realnej śmierci osób najbliższych. To, w jaki sposób dzieci sobie tłumaczą śmierć i żałobę, jest związane z etapem ich rozwoju poznawczego, emocjonalnego i fizycznego. Spojrzenie dziecka na zagadnienie śmierci i umierania zmienia się w zależności od wieku (Turner, Helms 1999, s. 51).

Przeżywając żałobę, często zapomina się o dzieciach. Wynika to czasami z braku wiedzy o tym, co dzieci czują, stykając się ze śmiercią. Dorośli nie potrafią odczytać myśli i uczuć dzieci, tego, jak przeżywają przykrość i smutek po stracie bliskiej osoby, gdyż ich zewnętrzne zachowanie nie wskazuje na przeżyty żal, tak jak u dorosłych. Jeśli szkoła chce pomóc dziecku w uporaniu się ze śmiercią bliskiej osoby, należy uwzględnić to, co się dzieje $\mathrm{w}$ rodzinie. Wzorce rodzinne i doświadczenia dziecka wyniesione z domu, z najbliższego 
otoczenia mają wpływ na sposoby reagowania dziecka na utratę bliskiej osoby. Każde dziecko i każda rodzina są jedyne w swoim rodzaju, należy rozpatrywać ich problemy indywidualnie (Herbert 2005, s. 33).

W wieku powyżej dziesięciu lat pogląd na śmierć u dziecka jest bardzo realistyczny, dla niego śmierć jest naturalną częścią życia. Należy podkreślić, iż fazy percepcji śmierci nie zawsze są związane z wiekiem, wpływ mają też czynniki społeczno-kulturowe, a także osobiste doświadczenia (Widera-Wysoczańska 1992).

Pełne zrozumienie śmierci i własnej przemijalności pojawia się w wieku młodzieńczym. Młodzież reaguje na śmierć w sposób zbliżony do dorosłych, jednak aktywność życiowa wypycha ze świadomości śmierć na dalszy plan (Wysoczańska 1988). Warto poddawać analizie poglądy i uczniów na temat śmierci i ich postawy wobec niej, poznawać uznawane przez nich wartości, dzięki czemu wzmaga się refleksyjność. Wtedy dochodzi do rozważań o charakterze aksjologicznym. Śmierć stanowi istotny element porządkujący, a także pozwala zweryfikować dotychczasowe priorytety życiowe (Ruman 2014). Należy spoglądać na śmierć „z pełnym realizmem i uczyć od najmłodszych lat wyciągania ze spotkania z nią niezbędnych wniosków. Śmierć dodaje nam bodźca do dobrego życia i zsyła nam pocieszenie w oczekiwaniu na przyszłą komunię z Chrystusem oraz z osobami, które były nam drogie. Daje nam więc pełny obraz egzystencji naszej i całego świata, wzmacnia naszego ducha w niezrównanej równowadze uczuć i myśli, wzbudza głęboką wdzięczność i podziw ku Bogu żywemu, Stwórcy wszechświata” (Paweł VI 1966, s. 398). „Nadzieja na cielesne zmartwychwstanie zmarłych pojawia się jako wewnętrzna konsekwencja wiary w Boga, Stwórcę całego człowieka, z duszą i ciałem” (Katechizm Kościoła Katolickiego, s. 249).

Chrześcijanie wierzą w ciała zmartwychwstanie i żywot wieczny. Śmierć jest postrzegana jako przejście przez próg do wiecznej rzeczywistości miłości, która jest trwalsza niż śmierć - to jest głównym celem życia każdego chrześcijanina i o takiej tajemnicy śmierci należy dzieciom mówić (Gretkowski 2003, s. 127-131).

W artykule proponowana jest koncepcja wychowania poprzez sztukę, która może być strategią radzenia sobie z rzeczywistością tanatologiczną. Chodzi o wkład, jaki pedagogika może wnieść na płaszczyźnie przygotowania człowieka do twórczego odbioru wszystkiego, co proponuje nam współczesna kultura.

Świadomość oddziaływania indoktrynacji, manipulacji, dokonywanych za pośrednictwem świata kultury pozwala na możliwość przeciwstawiania się szkodliwym wpływom, poprzez warsztaty czy publikacje, by przygotować młodzież do odbioru kultury, tak jak przygotowuje się ją, na przykład, do bezpiecznego uczestniczenia w ruchu drogowym. Do wypełnienia tego zadania inspiracji dostarcza nam tajemnica zawarta w wierze chrześcijańskiej (Adamczyk 2005; Chrobak 1999, s. 130). Wychowując, musimy być świadomi ideałów, systemów wartości, aby móc kształtować u innych określone uczucia, postawy, dążenia. Na kształt i rozwój wychowania duże oddziaływanie wywiera rozwój emocjonalny dziecka, szczególnie zaś jego związki z osobami z najbliższego otoczenia (Osewska 2004).

\section{Dziedzictwo kulturowe w edukacji}

W supermarkecie kultury pozornie każdy może robić wszystko, co chce, i wierzyć we wszystko, w co zechce, pod warunkiem, że nie krzywdzi innych ludzi. Jest to jednak złudzenie, ponieważ w momencie dokonywania wyboru nie jesteśmy już wolni, 
bo ukształtowani przez istniejącą kulturę, to ona wpływa na nasze życie. Pragnieniem i potrzebą każdego człowieka jest być tożsamym z dziedzictwem „własnego domu”. Supermarketyzacja kultury, czyli sprowadzenie jej do poziomu rynku, pozbawia jej odbiorców przeżywania autentycznego „zadziwienia” i „tajemnicy”, refleksji nad życiem i światem (Kawecki 2010).

Zanim dziecko nauczy się mówić, jest już małym tworem kultury, w której się narodziło. Wartości, zwyczaje i wierzenia właściwe danej kulturze stają się mu bardzo bliskie, to kultura stanowi psychologiczny mikroklimat, w którym wzrasta człowiek (Kowalczyk 1995, s. 359).

Prostym sposobem przygotowania, rozmowy, oswajania dziecka ze śmiercią jest stała pamięć o zmarłych. Oni żyją, interesują się nami i czekają na nas. Modlitwa za nich, uczestniczenie we Mszy św. sprawowanej za dusze w czyśćcu cierpiące, religijny udział w pogrzebie, nawiedzenie cmentarza - to wszystko wprowadza człowieka w prawdę o śmierci, która i tak pozostanie dla nas tajemnicą.

Ważna jest również rozmowa $\mathrm{z}$ dzieckiem. Postawa bliskich wobec dziecka w obliczu śmierci i żałoby w domu powinna wyróżniać się takimi elementami:

- rozmawiać z dzieckiem o zmarłej osobie (utrwalać pamięć);

- nie wyróżniać go, by źle nie zrozumiało, że powinno zająć miejsce osoby zmarłej (w przypadku śmierci rodzeństwa);

- należy okazywać zrozumienie dla uczuć dziecka i podzielać je;

- dziękować mu za jego obecność, by móc się wzajemnie wspierać;

- pozwalać dziecku na okazywanie wszelkich uczuć związanych z cierpieniem po stracie bliskiej osoby;

- przebywać razem z dzieckiem jak najczęściej. Należy pamiętać, że każdy indywidualnie przeżywa śmierć bliskich, $\mathrm{z}$ inną długością i głębią trwania (Grzywa 2013).

Cmentarze stanowią cenne źródło treści z zakresu regionalnego dziedzictwa kulturowego. Mają one nie tylko wartość artystyczną, historyczną, estetyczną i emocjonalną, ale przede wszystkim religijną, przypominają, że istnieje inny wymiar ludzkiej egzystencji. Wartości artystyczne cmentarzy przejawiają się zarówno w indywidualnych założeniach przestrzennych cmentarza, pomnikach, krzyżach, nagrobkach i innych elementach, jak też w symbolice grobu. Grób staje się pomnikiem wystawionym na czyjąś pamiątkę, zgodnie z przyjętymi w danym miejscu i w czasie zasadami kultu żałobnego. Jest monumentum i memoriałem jednocześnie. Z semantycznego punktu widzenia grób „mówi”, opowiada historię. Mówi przede wszystkim o myślącej istocie podległej prawom śmiertelności. Istotą tą jest człowiek, który nie tylko potrafi myśleć „o życiu”, „ku życiu”, o naoczności, ale jest zdolny wznieść się „ku niewidzialnemu” i w tym celu zaprzęga do służby przedmioty, kształtuje je odpowiednio i w rezultacie czyni z nich obraz, który znaczy (Wańczowski, Lenart 2009, s. 147). Cmentarze to swoiste teksty kultury, miejsca inwencji twórczej, łączące symbole poetyckie i religijne (Kolbuszewski 1985, s. 35). Dlatego też „cmentarz prawie zawsze i prawie wszędzie jest swoistą enklawą konserwatyzmu kulturowego” (Kolbuszewski 1994, s. 220), to znaczy miejscem świętym. Warto w czasie żałoby zabierać dzieci w te miejsca, przybliżać im historię zmarłych oraz dać swobodę rozmowy ze zmarłymi dziecku.

Tradycyjnie już początek listopada i poprzedzające go dni poświęcamy pamięci zmarłych. Pamięć ta zachęca do wiary, że ludzka egzystencja nie kończy się tu na ziemi, że 
istnieje życie po życiu, a każdy dzień ziemskiego życia jest drogą ku wieczności. Piękna tradycja powinna wciągać i najmłodszych.

Obrzędy i zwyczaje religijne stanowią wyraz religijności ludowej, która jest z kolei wyrazem świadomości ludu wyrosłej ze ścisłego związku z przyrodą i z niej wywodzącej swoje wyobrażenia o świecie, życiu i osobach (Keller 1978, s. 12). Szkoła powinna stymulować, wzmagać motywację do aktywniejszego udziału w kulturze. Kultura jest swoistym układem wartości (dóbr), wybieranych i realizowanych w określony sposób. Ich tworzenie nadaje sens życiu człowieka (Rodziński 1969, s. 111). Należy nauczać umiejętności wyboru dobra i „dobrowolnego” działania. Celem ostatecznym człowieka jest życie wieczne; ten nadprzyrodzony element zobowiązuje człowieka do jeszcze większej aktywności doczesnej (Piątek 1999, s. 59-61; Krąpiec 2004, s. 10-13).

Scalającą człowieka i kulturę wartością jest moralność, zadaniem kultury jest budzenie sumień prowadzące do cywilizacji godności i wolności. Należy bronić kultury bazującej na uniwersalistycznych, pozytywnych wartościach. Kultura, jak i refleksja nad nią, jest sprawą żywą i aktualną (Truchlińska 2001).

\section{Rola sztuki religijnej w edukacji}

Relacja między kulturą a religią nie powinna iść w kierunku rozłączności czy wzajemnego szukania nadrzędności, lecz w kierunku twórczej korespondencji albo twórczej kooperacji między nimi. Dopiero wtedy można mówić o indywidualnym i społecznym wymiarze personalizmu chrześcijańskiego, czyli o „persono-twórczej” i „communio-twórczej” roli chrześcijaństwa, tzn. tworzącego człowieka i społeczeństwo i (Rusecki 2003).

Reakcja na sztukę zaczyna się od aktu percepcji, jednak właściwe rozumienie psychologii sztuki zrodzić się może z teorii wyobraźni i odczuwania. Sztuka zawiera w sobie zawsze afektywną sprzeczność, wzbudza wzajemnie przeciwstawne nurty uczuć i doprowadza je do krótkiego spięcia i likwidacji. Określa się to mianem katharsis, czyli do skomplikowanej przemiany uczuć. W tej przemianie dochodzi do rozładowania emocji, które zostały wzbudzone - na tym polega katharsis reakcji estetycznej (Wygotski 1980).

Należy stwarzać warunki dla prezentowania twórczości artystycznej inspirowanej wartościami religijnymi, aby w ten sposób, dając przeżycie estetyczne, przybliżać ludzi do najwyższego Piękna, do Boga. Wychowanie przez sztukę, w tym sakralną, jest drogą realizacji integralnego wychowania człowieka (Nowak 2006).

Religia i kultura są autonomiczne, ale nie należy ich rozdzielać - obowiązuje tu zasada dividuntur sed non separentur. Nie można też utożsamiać tych dwóch terminów, kultura dotyczy natury i świata, religia natomiast - transcendencji (Kawecki 2006, s. 113). Kultura religijna znosi sztuczne granice miedzy sacrum a profanum, antynomię miedzy ciałem a duszą, światem obecnym a przyszłym. „Osoba jest najwyższym źródłem i zarazem celem kultury” (Bartnik 1999, s. 4). Kulturą jest zatem życie człowieka, a Jan Paweł II powiedział: „Przyszłość człowieka zależy od kultury” (Jan Paweł II 1988, s.17). Człowiek jest osobą, natomiast staje się osobowością. Wychowanie, nie naruszając natury i struktury osoby, może sprawić, że człowiek staje się sobą. Rozwój osobowości dokonuje się w relacji: "my” - ma charakter związku bliskiego, immanentnego, „wy” - umożliwia porozumienie społeczne, „oni” - wprowadza w uniwersalną, transcendentną rzeczywistość, w której 
człowiek staje się zdolny do przyjęcia wartości najwyższych, otwiera się na obecność osobową Boga (Mastalski 1998).

Nie można tylko mówić o pięknie, ale trzeba stworzyć szansę na jego doświadczenie: zobaczenie, usłyszenie, czucie. Należy położyć akcent na ciekawe wydarzenia kulturalne, które dla dzieci okażą się wspaniałą przygodą ze sztuką, wykorzystać bogactwo repertuaru polskich instytucji kulturalnych. Ważne by wykorzystać i umieć wybrać odpowiednie dla dzieci propozycje: uczestniczenie w koncercie stanowi dla dzieci źródło nowych, rozwijających doświadczeń i bogatych estetycznych przeżyć. Wyjście poza środowisko, w którym żyją na co dzień, zorganizowanie np. wyjazdu do muzeum malarstwa, gdzie można poznać nowe formy wyrazu artystycznego, to w wartościowy sposób spędzenia czasu wolnego. Nauka tańca - to piękno muzyki, kolorowe stroje - tworzą magiczną atmosferę, jest to również bardzo silny bodziec w rozwoju wrażliwości na piękno. Wysłuchanie chóru jest okazją przeżycia niezwykłej przygody ze sztuką, gdyż dzieci noszą w swoich sercach i umysłach ukryte pragnienie piękna i dobra, zrealizowanie tych pragnień to cel pracy wychowawczej i terapeutycznej. Przed wychowawcami stoi ważne zadanie, aby wskazywać dzieciom piękno, stwarzać przestrzeń i dogodne warunki do poznania go, gdyż ono budzi wrażliwość, uszlachetnia i leczy (Remiasz 2010).

Świat wyobraźni formowany jest od dzieciństwa, poddawany różnym perturbacjom, różnicuje się w trakcie dorastania i doświadczeń. Wiemy, iż jednym z zadań kultury jest prowadzić człowieka w kierunku świętości (Rudin 1992).

\section{Prawda o śmierci i nieśmiertelności w wybranych obrazach sztuki sakralnej}

Wielkim problemem współczesnej kultury jest bezradność wobec śmierci. Proces umierania zostaje wyrzucony poza nawias życia społecznego, staje się często tematem tabu. Zanikają tradycje ludowe, które pozwalały oswoić się z nią, nie ma więc sposobów , które by pomagały mniej się bać. Człowiek staje wobec śmierci samotny, nie znający oparcia w otoczeniu społecznym (Kruczkowska 1983).

Śmierć jest sytuacją, w której człowiek doświadcza w sposób osobowy całkowitej bezradności. Uczuciem związanym z tą sytuacją jest lęk. Tanatopsychologia zajmuje się szeroko rozumianą problematyką postawy wobec śmierci, a zwłaszcza lęku przed śmiercią, bada i wyjaśnia wszelkie uwarunkowania, właściwości i korelaty lęku tanatycznego, czyli lęku wobec śmierci (Makselon 1988).

Śmierć jest ostatecznym uwolnieniem w świecie zewnętrznym. Wolnością prawdziwą jest tylko śmierć, gdyż w świecie życia ludzkiego jest zawsze tylko zależność lub współzależność, ale nigdy nie wolność. Postać osamotnienia w umieraniu jest próbą człowieczeństwa bezwzględną, o której nie wiemy nic, żadna wyobraźnia nam tego nie powie. Niewielu może wypowiedzieć swoją osobistą wizję umierania w takim języku jak Amadeusz Mozart swoim Requiem. Lecz nawet ten język bardzo mało mówi żyjącym o umieraniu - a cóż dopiero o śmierci, która jest milczeniem (Szczepański 1978, s. 196-197).

Jeśli śmierć pojmuje się jako utratę świadomości, to nie ma spotkania z własną śmiercią. Śmierć wcale nas nie dotyczy - argumentował Epikur - bo gdy my istniejemy, śmierć nie jest obecna, a gdy tylko śmierć się pojawi, wtedy nas już nie ma. Wobec tego śmierć nie miałaby żadnego związku ani z żywymi, ani z umarłymi. Można przeżywać zbliżanie się śmierci 
(gdy ktoś jest nieuleczalnie chory), ale samej śmierci własnej nikt nigdy nie przeżył. Nie można jej także poznać przez wgląd w śmierć drugiego człowieka (Ziemiński 1999).

Religia pozwala uporać się ze świadomością śmierci na płaszczyźnie poznawczej i doświadczalnej (przeżyciowej), to ona daje świadome bezpieczeństwo w sytuacji ciągłego przemijania. Chrześcijanin nadaje śmierci sens przejścia do Ojca, czyni to zwykle po głębszym przeżyciu swej wiary i swego egzystencjalnego związku z Jezusem - racją jego nadziei na nieśmiertelność jest sam Jezus i jego obietnica: „Ja jestem zmartwychwstaniem” (J 11, 25). Dostrzega granice władzy nad sobą i kruchość własnej egzystencji, w wolności powierza się Bogu, od którego oczekuje nieśmiertelności jako daru życia wiecznotrwałego (Siemianowski 1991).

Prawda o śmierci i nieśmiertelności nie ma charakteru prawdy naukowej czy racjonalnie dowiedzionej filozoficznej teorii. Śmierć i nieśmiertelność są tajemnicami żywej egzystencji, zadaniem i powołaniem poszczególnego człowieka, które tylko on sam może „rozwiązać”, stając się sobą w wolności i w prawdzie. Odpowiedzi na pytanie o egzystencjalne prawdy o śmierci i nieśmiertelności człowiek szuka w religii. Ważne jest to, by człowiek, który zdecydowany jest żyć w prawdzie, dostrzegał w śmierci sens, umierał ze spokojem, z poczuciem jakichś racji, z ufnością, z chrześcijańską nadzieją na życie wieczne. Obojętnie jak człowiek się w ustosunkuje, w wolności, do swej śmierci i jak ją zechce przeżywać, już za życia w swej codziennej egzystencji „dokonuje wyboru swej wiecznej wartości” (Kirkegaard 1976, s.36), w każdym bowiem określeniu się wobec śmierci w jakiś sposób rozstrzyga także o swej osobistej nieśmiertelności. Problematyka śmierci ma nie tylko wymiar metafizyczny i ogólnoludzki, lecz także społeczno-kulturowy (Ruman 2011).

Przykładową koncepcję faz przeżywania żałoby przedstawił Robert Kavenaugh, który wyróżnił następujące stadia: 1) szok, 2) dezorganizacja, 3) zmienne emocje, 4) poczucie straty i osamotnienia, 5) ulga (sytuacja staje się łatwiejsza do zniesienia) i w końcu 6) ponowne ustabilizowanie się. Doświadczenie śmierci pozostawia trwałe piętno i na zawsze odmienia ludzkie życie. Dlatego ważna jest obecność innych, którzy próbują zrozumieć i współczuć (Lis-Turlejska 1989).

Rola osób towarzyszących w żałobie jest nie łatwa i niewdzięczna. Osoby postronne nie powinny narzucać się z pomocą ani $\mathrm{z}$ „dobrymi radami”. Jedyne co można, to być, słuchać, pozwolić dziecku na wypłakanie się, użalenie czy nawet na wykrzyczenie swoich emocji, gdyż ono w ten sposób może oswoić swój ból. Wychowawca powinien pytać, chociaż po raz kolejny może usłyszeć odmowę, czy w czymś nie pomóc. Wiara pozwala spojrzeć na to, co się stało, w świetle Zmartwychwstania, i zrozumieć, że pożegnanie zmieni się kiedyś $\mathrm{w}$ radosne powitanie $\mathrm{w}$ wieczności.

Cmentarz posiada pewne walory artystyczne i może być cennym zabytkiem sztuki rzeźbiarskiej. Obserwując plastykę nagrobną na cmentarzach wielowyznaniowych, można wskazać wiele motywów religijnych i egzystencjalnych. Odczytywanie symbolicznych znaczeń cmentarza może odbywać się na dwóch płaszczyznach - w postaci kodów werbalnych przekazywanych przez inskrypcje nagrobne oraz kodów niewerbalnych, takich jak: formy nagrobków, krzyże, rzeźby figuralne i ich atrybuty, elementy roślinne, płaskorzeźbione znaki plastyczne (oko opatrzności, uskrzydlona klepsydra, wąż zjadający swój ogon, motyl itp.), popiersia i fotografie nagrobne. Projektanci bardzo umiejętnie kojarzyli symbolikę śmierci z symbolami życia, jakimi są światło i żywa zieleń (Sobczak 2005). Wszystko to poprzez swoją symbolikę staje się swoistym, często ukrytym komunikatem dla żyjących. 
Spojrzenie na przeszłość przez epitafia z pewnością daje obraz krańcowo subiektywny, one kreują mikrorzeczywistość niedotykalną i jednocześnie niezwykle realną (Tyszka 200o). W najstarszych zakątkach nekropolii można znaleźć wzruszające stare inskrypcje, warto się zadumać nad prostotą tych tekstów. Przykładowo: Sum quod eris, quod es dim fui (Jestem czym będziesz, czym jesteś, niegdyś byłem).

Obraz ukrzyżowanego Chrystusa pełni funkcję wyjaśniania ludzkiej i egzystencji. Sztuka ma także inspirować do refleksji nad stanem moralnym, skłania do refleksji nad samym sobą, do odpowiedzi na pytanie: kim jestem? Poprzez przekaz obrazu z krzyżem odbiorcy zostaje uświadomiony pewien fakt z życia ludzkiego zamykający się w ramach: los, cierpienie, śmierć. Pojawia się motyw transcendencji. Swoisty lęk przed śmiercią łączony jest $\mathrm{z}$ lękiem przed losem, co związane jest $\mathrm{z}$ ujmowaniem własnego życia w kategoriach nawiązujących do pojęć używanych przez egzystencjalistów w opisie kondycji ludzkiej: Heideggerowski motyw człowieka będącego „bytem ku śmierci” czy Sartre’owski motyw „Zagubienia i nicości” (Gałuszka, Kowalewicz 1987).

W krzyżu $i$ zmartwychwstaniu Chrystusa już dokonuje się przejście do nowego czasu. Eschatologiczne „być już” jest obecne $w \dot{z} y c i u$ jednostki, a wraz $z$ jednostką $w \dot{z} y c i u$ świata. Rudolf Bultmann, teolog, twierdzi, że „być chrześcijaninem, tzn. egzystować eschatologicznie". Tajemnica eschatologii powinna być wpisana $w$ sam rdzeń ludzkiego bytu (Koch 2000). Nasza duchowa nieprzemijająca egzystencja nie jest zewnętrznym dodatkiem, który następuje po istnieniu cielesnym, śmiertelnym; jest ona raczej nieskończonym fundamentem, na którym dopiero budujemy swoje doczesne istnienie (Beck 2001).

Sztuka daje nadzieję, która rozprasza rozpacz egzystencji. Starożytnym środkiem przekazu określonej rzeczywistości duchowej jest ikona. Przykładowo ikona Jerzego Nowosielskiego pt. Zejście do otchłani ustanawia pewne warunki pozwalające wymiary duchowe odnaleźć w sobie i przeżyć. Przeżyć, by wytworzył się obszar wewnętrznej wolności od lęku przed nicością śmierci. „Ujrzenie dobra jako maski, pustka i samotność, rozpacz i umieranie wewnętrzne - to bycie w piekle uczuć. Jezus pokazuje drogę i kierunek starożytnej sentencji «poznaj samego siebie», ikona jest terapią, jest odpowiedzią na brak w pamięci u niektórych chrześcijan o zstąpieniu Jezusa do piekieł po zmartwychwstaniu. Widać to na gruncie osobowym jako nie akceptację ciemnej strony siebie i działania według reguły "muszę być dobry i miły», a ikona uaktualnia pytanie, jaka jest wola człowieka, Jezus może nas przeprowadzić, jeżeli Mu na to pozwolimy, uwolnimy się od błędu, wydostaniemy się z emocjonalnego piekła" (Perszko 1997, s.72-75). Ikona Zmartwychwstania Jezusa pokazuje możliwość potencjalnego przemienienia człowieka, pokazuje sens śmierci i zmartwychwstania.

Większość ludzi przeżywa i odczuwa instynktownie taką sztukę, która jest dążeniem do ładu i harmonii, które zostały zachwiane w społeczeństwie, jak i w nich samych. Wychowanie przez sztukę będzie wtedy skuteczne, gdy tworzenie i odbiór piękna będzie przenikał całe życie (Rudniański 1984).

\section{Zakończenie}

Religia chrześcijańska jest nadzieją - „Wierzę w żywot wieczny”. Oznacza to, że dla chrześcijan „Bóg nie jest Bogiem umarłych, lecz żywych” (Mt 22,32). Biblijna nadzieja kieruje się ku przyszłości, lecz ku takiej, która już się zaczęła, jest zakorzeniona 
w teraźniejszości. Jeśli bowiem Zbawienie Boże dokonuje się rzeczywiście w historii, to musi mieć jakieś znaczenie dla tej historii i musi w niej znajdować swoją przyszłość. Przyszłość została złożona w nasze ręce. Nadzieja chrześcijańska przekracza wymiar rzeczywistości ziemskiej, gdyż głównym jej założeniem jest otwarcie się na przyszłą pełnię Objawienia Bożego w Chrystusie. Przez śmierć Chrystusa nasza śmierć zyskała sens definitywnie pozytywny, jest przejściem do życia w pełni, ekspansją naszego bytu. Różnorodne wyrzeczenia towarzyszące nam w ciągu życia są swoistym przygotowaniem na śmierć, pozwalają nam one zrozumieć, jak jesteśmy bezgranicznie ubodzy (Page 1997).

Sztuka potrafi wyrazić i uczynić widoczną ludzką potrzebę wykraczania poza to, co widzialne, ukazuje pragnienie i poszukiwanie nieskończoności. Co więcej, jest jakby bramą otwartą ku nieskończoności, ku pięknu i prawdzie, wykraczającymi poza codzienność. Istnieją także wypowiedzi artystyczne będące prawdziwymi ścieżkami do Boga - Najwyższego Piękna, są one wręcz pomocą w modlitwie. „Chodzi o dzieła, które rodzą się z wiary i wyrażają wiarę. Przykładowo, gdy odwiedzamy gotycką katedrę, nasze oczy i nasz duch pociągnięte zostają ku górze, podczas gdy równocześnie odczuwamy swą małość chociaż pragniemy pełni. Również, gdy słyszymy fragment muzyki sakralnej, nasza dusza jest jakby poszerzona i łatwiej jej zwracać się do Boga. Należy zachęcać do odkrycia na nowo znaczenia tej drogi także dla modlitwy, dla naszej żywej więzi z Bogiem. Miejmy nadzieję, że Pan pomoże nam rozpamiętywać Jego piękno zarówno w przyrodzie, jak i w dziełach sztuki, i w ten sposób, dotknięci światłem Jego oblicza, także my będziemy światłem dla naszych bliźnich" (Benedykt XVI 2011, s. 5).

Szczególnym nosicielem piękna jest dzieło sztuki, w tym sztuki religijnej. Jan Paweł II w Liście do artystów pisał m.in.: „Kościół nadal żywi bardzo wysokie uznanie dla sztuki jako takiej. Sztuka bowiem, jeżeli jest autentyczna, choć niekoniecznie wyraża się w formach typowo religijnych, zachowuje więź wewnętrznego pokrewieństwa ze światem wiary [...]. Jako poszukiwanie prawdy, owoc wyobraźni wykraczającej poza codzienność, sztuka jest ze swej natury swoistym wezwaniem do otwarcia się na tajemnicę". Dzięki sztuce rzeczywistość duchowa, niematerialna staje się postrzegalna. Obraz, rzeźba, architektura, muzyka, tworzone z inspiracji biblijnej świadczą o tym, że w „sferze religii człowiek zadaje najważniejsze pytania osobiste i poszukuje ostatecznych odpowiedzi egzystencjalnych". Dzięki dziełu sztuki „ludzkość po każdym upadku będzie mogła wciąż dźwigać się i zmartwychwstawać. W tym właśnie sensie powiedziano z proroczą intuicją, że Piękno zbawi świat” - stwierdzał Jan Paweł II (Jan Paweł II 1999).

O patronie artystów Jan Paweł II powiedział: „Fra Angelico pędzlem wypowiedział swoją summę Bożych tajemnic, podobnie jak Tomasz z Akwinu wypowiedział ją językiem teologii. W dziełach jego barwy i kształty oddają pokłon świętemu przybytkowi Boga i głoszą szczególne dziękczynienie Jego imieniu. Niezwykły, mistyczny urok malarstwa Brata Angelico każe nam zatrzymać się w zachwycie wobec geniuszu, jakim jest rozum ludzki, którym dobry Bóg obdarza prawych, tych co są czystego serca [...]. Do ostatnich swych dni wytrwale łączył zakonne i artystyczne obowiązki. Sława skromnego zakonnika przetrwała wieki. Poprzez świętość swego natchnienia tworzył dzieła jedyne, nieporównywalne z tym wszystkim, co istniało przed nim, co stworzono po nim. Jego sztukę określano jako anielską, a jego życie - świątobliwym. Nie wziął nigdy do ręki pędzla, zanim nie odmówił modlitwy. Za każdym razem, gdy malował krucyfiks, jego policzki zroszone były łzami. Każdą postać Chrystusa malował na klęczkach. Swój talent 
uważał za depozyt Boga, który tylko Jemu mógł służyć. U Fra Angelico sztuka i głęboka religijność pozostawały nierozdzielne (B.a. 2007, s. 63).

Warto, by sztuka w przyszłości, szukając wciąż nowych środków wyrazu, co jest jej powinnością i zaletą, miała znowu coś ważnego do powiedzenia w czasach wielkiego, globalnego przełomu cywilizacyjnego. Sztuka bowiem od początku buduje nasze człowieczeństwo.

\section{Bibliografia}

Adamczyk D. (2005). Wychowanie do budowania kultury chrześcijańskiej. „Communio”, nr 4, s. 127-138.

Arystoteles. (1989). Poetyka, tłum. Podbielski H., Wrocław: Wydawnictwo Ossolineum.

B.a. (2007). Kaznodzieja pędzla. „Gość Niedzielny”, nr 4, s. 63.

Bartnik Cz. (1999). Teologia kultury. Lublin: Katolicki Uniwersytet Lubelski.

Beck H. (2001). Czas jako „odbicie” wieczności, tłum. Mendyk E., „Communio”, nr 6, s.67-83.

Benedykt XVI. (2011). Katecheza środowa. „Gość Niedzielny”, nr 36, s. 5.

Chrobak S. (1999). Koncepcja wychowania personalistycznego w nauczaniu Karola Wojtyly - Jana Pawła II. Warszawa: Wydawnictwo Salezjańskie.

Gałuszka M., Kowalewicz K. (1987). Ikonografia religijna w odbiorze potocznym. „Euhemer - Przegląd Religioznawczy", nr 3-4, s. 119-129.

Gretkowski A. (2003). Ból i cierpienie. Płock: Wydawnictwo NOVUM.

Grzywacz A. (2013). Jak oswoić się z myśla o starości, umieraniu i śmierci. Lublin: Wydawnictwo Słowa i Myśli.

Herbert M. (2005). Żałoba w rodzinie, tłum. Gajdzińska M., Gdańsk: Gdańskie Wydawnictwo Psychologiczne, s. 33n.

Jan Paweł II. (1988). W imięprzyszłości kultury. Do przedstawicieli UNESCO Paryż 2 czerwca 1980. W: Radwan M., Gorzkula T., Cywińska K. (oprac.). Jan Paweł II. Wiara i kultura. Dokumenty, przemówienia, homilie. Rzym - Lublin: Wydawnictwo Polski Instytut Kultury Chrześcijańskiej. Fundacja Jana Pawła II.

Jan Paweł II. List do artystów, dostępny na: (http://www.opoka.org.pl/biblioteka/W/WP/ Jan_Pawel_II/listy/do_artystow_04041999.html (otwarty 28.09.2014).

Katechizm Kościoła Katolickiego, Pallotinum Poznań 1994.

Kawecki W. (2010). Kultura konsumpcyjna a wychowanie do kultury wysokiej. „Studia Theologica Varsaviensia", nr 2, s. 179-185.

Kawecki W. (2006). Personalistyczna koncepcja teologii kultury. „Studia Theologica Varsaviensia", nr 1, s. 191-204.

Keller J.(1978). Zwyczaje, obrzędy i symbole religijne. Warszawa: Wydawnictwo Iskry.

Kierkegaard S. (1976). Albo-albo, tłum. Iwaszkiewicz J. Warszawa: PWN, t. 1, s. 36.

Koch K. (2000). Eschatologia chrześcijańska w krzyżowym ogniu apokaliptyki. „Communio”, nr 4, s. 87-89.

Kolbuszewski J. (1994). Cmentarza pejzaż semiotyczny. „Przegląd Powszechny”, nr 879, s.216-224.

Kolbuszewski J. (1985). Wiersze z cmentarza. O współczesnej epigrafice wierszowanej. Wrocław: Wydawnictwo Polskie Towarzystwo Ludoznawcze. 
Kowalczyk S. (1995). Podstawy światopoglądu chrześcijańskiego. Wrocław: Wrocławska Księgarnia Archidiecezjalna TUM.

Krąpiec M. A. (2004). Sens kultury chrześcijańskiej. Lublin: Fundacja SERVIRE VERITATI, Instytut Edukacji Narodowej.

Kruczkowska A. (1983). Ewolucja postaw wobec śmierci. Średniowiecze a współczesność. „Studia Psychologiczne”, nr 1-2, s. 117-125.

Lis-Turlejska M. (1989). Problematyka przeżywania utraty w psychologii klinicznej. „Przegląd Psychologiczny", nr 3, s. 749-761.

Makselon J. (1988). Lęk wobec śmierci. Wybrane teorie i badania psychologiczne. Kraków: Wydawnictwo Polskie Towarzystwo Teologiczne.

Mastalski J. (1998). Elementy teorii wychowania dla katechety. W: M. Śnieżyński (red.). Pedagogika w katechezie. Kraków: Wydawnictwo WAM.

Osewska E. (2004). Katecheza dzieci w wieku przedszkolnym. „Ateneum Kapłańskie”, nr 569-574, z. 1, s. 7-11.

Page J. G. (1997). Życie rodzi się tylko ze śmierci, tłum. Balter L. „Communio”, nr 11, s. 221-225.

Paweł VI (1966). Niech spłynie na nas z grobów pokój (Przemówienie z Bazyliki Watykańskiej $z 2$ XI). „Gość Niedzielny”, nr 11.

Perszko D. (1997). Rola obrazu religijnego w rozwoju osobowości. „HEKSIS”, nr 3, s. 72-75.

Piątek J. (1999). Kulturotwórcze elementy antropologii. W: Łukomski J. (red.). Kultura a nasze istnienie. Kielce: Wydawnictwo Jedność.

Remiasz E. (2010). Jak budzić w dzieciach wrażliwość na sztukę? „Remedium”, nr 7-8, s. 12-14.

Rodziński A. (1969). Kultura i chrystianizm. „Roczniki Filozoficzne”, t.4.

Rudin J. (1992). Psychoterapia i religia, tłum. Tarnowska M, Warszawa: Wydawnictwo Naukowe PWN.

Rudniański J. (1984). Człowiek i sztuka. Warszawa: Instytut Wydawniczy Związków Zawodowych.

Ruman N. M. (2011). Psychologiczny, teologiczny i społeczno-kulturowy wymiar śmierci $i \dot{z} a ł o b y$. Katowice - Kraków: Wydawnictwo Scriptum.

Ruman N. M. (2014). Znaczenie antropologii wychowania integralnego na kanwie nauczania Jana Pawła II w percepcji eschatologicznej. W: Ogrodzka-Mazur E., Błahut G., Ruman N. M. (red.). Wychowanie dziecka - między tradycją a współczesnością. Toruń: Wydawnictwo Adam Marszałek, s. 115-135.

Rusecki M. (2003). Fenomen chrześcijaństwa. Wkład w kulturę. Lublin: Katolicki Uniwersytet Lubelski.

Siemianowski A. (1991). Śmierć i nieśmiertelność. W filozofii i w życiu codziennym. „Znak”, nr 2, s. 47-49.

Szczepański J. (1978). Sprawy ludzkie. Warszawa: Wydawnictwo Czytelnik.

Truchlińska B. (2001). Kultura i wartości. „Ruch Filozoficzny”, nr 1, s. 15-18.

Turner J. S., Helms D. B. (1999). Rozwój człowieka. Warszawa: Wydawnictwa Szkolne i Pedagogiczne.

Tyszka A. T. (200o). W nekrologach - samo życie. „Mówią Wieki”, nr 11, s. 6-11.

Wańczowski M., Lenart M. (2009). Księga żałoby i śmierci. Warszawa: Oficyna Wydawnicza RYTM.

Wygotski L. (1980). Psychologia sztuki. Kraków: Wydawnictwo Literackie. 
Widera-Wysoczańska A. (1992). Świat dziecięcych doświadczeń związanych ze śmiercią. „Nowiny Psychologiczne”, nr 2, s. 96-103.

Wysoczańska A. (1988). Problemy śmierci w pogladach młodych ludzi. „Zdrowie Psychiczne”, nr 3-4, s. 157-165.

Ziemiński I. (1999). Zagadnienie śmierci w filozofii analitycznej. Lublin: Katolicki Uniwersytet Lubelski.

\title{
SACRED ART AND THANATOLOGICAL EXPERIENCE - PEDAGOGICAL AND THEOLOGICAL ASPECT
}

\begin{abstract}
Education through art, which is to lead to human development and to balance intellectual, emotional and motivational-volitional aspects, is often overlooked problem. Art should control our lives. World of imagination is formed since childhood, subjected to various perturbations and differentiated during adolescence and experiences. These are also the experience unpleasant, sad and difficult. Sacred art does not ignore such sensations in human life. It represents death, which is a taboo subject, in such a way as to encourage the recipient to reflect and enrich his or her life. Therefore art becomes a tool for the overall development of human beings which is to enable man to live in a spontaneous and creative way and to help achieve harmony of sensual, emotional and intellectual life.
\end{abstract}

Key words: alternative education, education, culture, art, the meaning of life, thanatology, eschatology

Natalia Maria Ruman - doktor nauk społecznych w zakresie pedagogiki, licencjat kanoniczny teologii. Absolwentka Uniwersytetu Śląskiego. Pracuje jako wychowawca i katecheta w Powiatowym Zespole Szkół nr 2 im. K. Miarki w Pszczynie. Adres do korespondencji: Uniwersytet Śląski, Wydział Etnologii i Nauk o Edukacji, ul. Bielska 62, 43-40o Cieszyn. Adres e-mail: nruman@interia.pl 